Supplement of Biogeosciences, 17, 515-527, 2020

https://doi.org/10.5194/bg-17-515-2020-supplement

(c) Author(s) 2020. This work is distributed under

the Creative Commons Attribution 4.0 License.

(c) (i)

Supplement of

\title{
The carbon footprint of a Malaysian tropical reservoir: measured versus modelled estimates highlight the underestimated key role of downstream processes
}

Cynthia Soued and Yves T. Prairie

Correspondence to: Cynthia Soued (cynthia.soued@gmail.com)

The copyright of individual parts of the supplement might differ from the CC BY 4.0 License. 


\section{$\underline{\text { Supplementary information content: }}$}

- Table S1: Summary of the mean, standard deviation (SD), range (min and max), and number of observation (n) of physical and chemical variables measured at the surface of the reservoir and its inflows.

- Figure S1: Example of a profile of temperature, $\mathrm{CO}_{2}$ and $\mathrm{CH}_{4}$ concentrations in the main basin of the reservoir (site right upstream of the dam).

- $\quad$ Figure S2: Maps of the spatially interpolated surface $\mathrm{CO}_{2}$ diffusion in Batang Ai reservoir for each sampling campaign. Unit is in $\mathrm{mmol} \mathrm{m}^{-2} \mathrm{~d}^{-1}$. Graph axes are the spatial coordinates (latitude and longitude).

- $\quad$ Figure S3: Maps of the spatially interpolated surface $\mathrm{CH}_{4}$ diffusion in Batang Ai reservoir for each sampling campaign. Unit is in $\mathrm{mmol} \mathrm{m}^{-2} \mathrm{~d}^{-1}$. Graph axes are the spatial coordinates (latitude and longitude).

- $\quad$ Figure S4: Simulated below dam emissions (degassing + downstream emissions) of $\mathrm{CO}_{2}$ (gray squares) and $\mathrm{CH}_{4}$ (dark circles) under different water withdrawal depth raise. Simulated emissions do not take into account $\mathrm{CH}_{4}$ oxidation in the outflow river.

- Table S2: Equations used to derive modeled $\mathrm{CO}_{2}$ and $\mathrm{CH}_{4}$ emissions based on the G-res and Barros et al. models. Input variables are described in Table S3.

- Table S3: Input variables values, units, and sources used in the modeling of Batang Ai $\mathrm{CO}_{2}$ and $\mathrm{CH}_{4}$ emissions.

\section{- Modeling downstream river oxidation}

\section{- $\quad$ References}


Table S1: Summary of the mean, standard deviation (SD), range (min and max), and number of observation (n) of physical and chemical variables measured at the surface of the reservoir and its inflows.

\begin{tabular}{|c|c|c|c|c|c|c|c|c|c|c|c|}
\hline \multirow[b]{2}{*}{ Variables } & \multirow[b]{2}{*}{ Units } & \multicolumn{5}{|c|}{ Reservoir } & \multicolumn{5}{|c|}{ Inflows } \\
\hline & & Mean & SD & Min & Max & $\mathrm{n}$ & Mean & SD & Min & Max & $\mathrm{n}$ \\
\hline Water temperature & $\stackrel{\circ}{ } \mathrm{C}$ & 31 & 0.8 & 24 & 32 & 134 & 27 & 2.4 & 24 & 30 & 10 \\
\hline DOC & $\mathrm{mg} \mathrm{L}^{-1}$ & 0.9 & 0.2 & 0.3 & 1.8 & 115 & 0.8 & 0.4 & 0.4 & 1.3 & 8 \\
\hline TP & $\mu \mathrm{g} \mathrm{L}^{-1}$ & 5.9 & 2.4 & 2.8 & 23.3 & 114 & 20.7 & 7.6 & 11.7 & 36 & 8 \\
\hline TN & $\mathrm{mg} \mathrm{L}^{-1}$ & 0.11 & 0.04 & 0.06 & 0.33 & 115 & 0.14 & 0.04 & 0.07 & 0.19 & 8 \\
\hline Chla & $\mu g \mathrm{~L}^{-1}$ & 1.3 & 0.7 & 0.3 & 4.0 & 112 & 2.1 & 1.7 & 0.1 & 4.4 & 9 \\
\hline $\mathrm{CO}_{2}$ diffusion & $\mathrm{mmol} \mathrm{m} \mathrm{m}^{-2} \mathrm{~d}^{-1}$ & 7.7 & 18.2 & -30.8 & 80.0 & 129 & 137.3 & 192.4 & 9.7 & 593.9 & 8 \\
\hline $\mathrm{CH}_{4}$ diffusion & $\mathrm{mmol} \mathrm{m} \mathrm{m}^{-2} \mathrm{~d}^{-1}$ & 0.6 & 0.6 & 0.03 & 3.7 & 129 & 30.7 & 37.4 & 1.2 & 113.4 & 8 \\
\hline $\mathrm{N}_{2} \mathrm{O}$ diffusion & $\mathrm{nmol} \mathrm{m} \mathrm{m}^{-2} \mathrm{~d}^{-1}$ & -0.2 & 2.1 & -7.1 & 2.7 & 15 & & & & & 0 \\
\hline$\left[\mathrm{CO}_{2}\right]$ & $\mu \mathrm{mol} \mathrm{L}^{-1}$ & 16.3 & 5.2 & 6.8 & 36.2 & 132 & 60.1 & 34.9 & 10.1 & 113.5 & 10 \\
\hline$\left[\mathrm{CH}_{4}\right]$ & $\mu \mathrm{mol} \mathrm{L}^{-1}$ & 0.2 & 0.2 & 0.0 & 1.2 & 137 & 6.6 & 4.3 & 0.6 & 14.8 & 10 \\
\hline$\left[\mathrm{N}_{2} \mathrm{O}\right]$ & $\mathrm{nmol} \mathrm{L-1}$ & 5.6 & 1.2 & 3.9 & 7.8 & 15 & 6.1 & & 5.2 & 7.0 & 2 \\
\hline
\end{tabular}



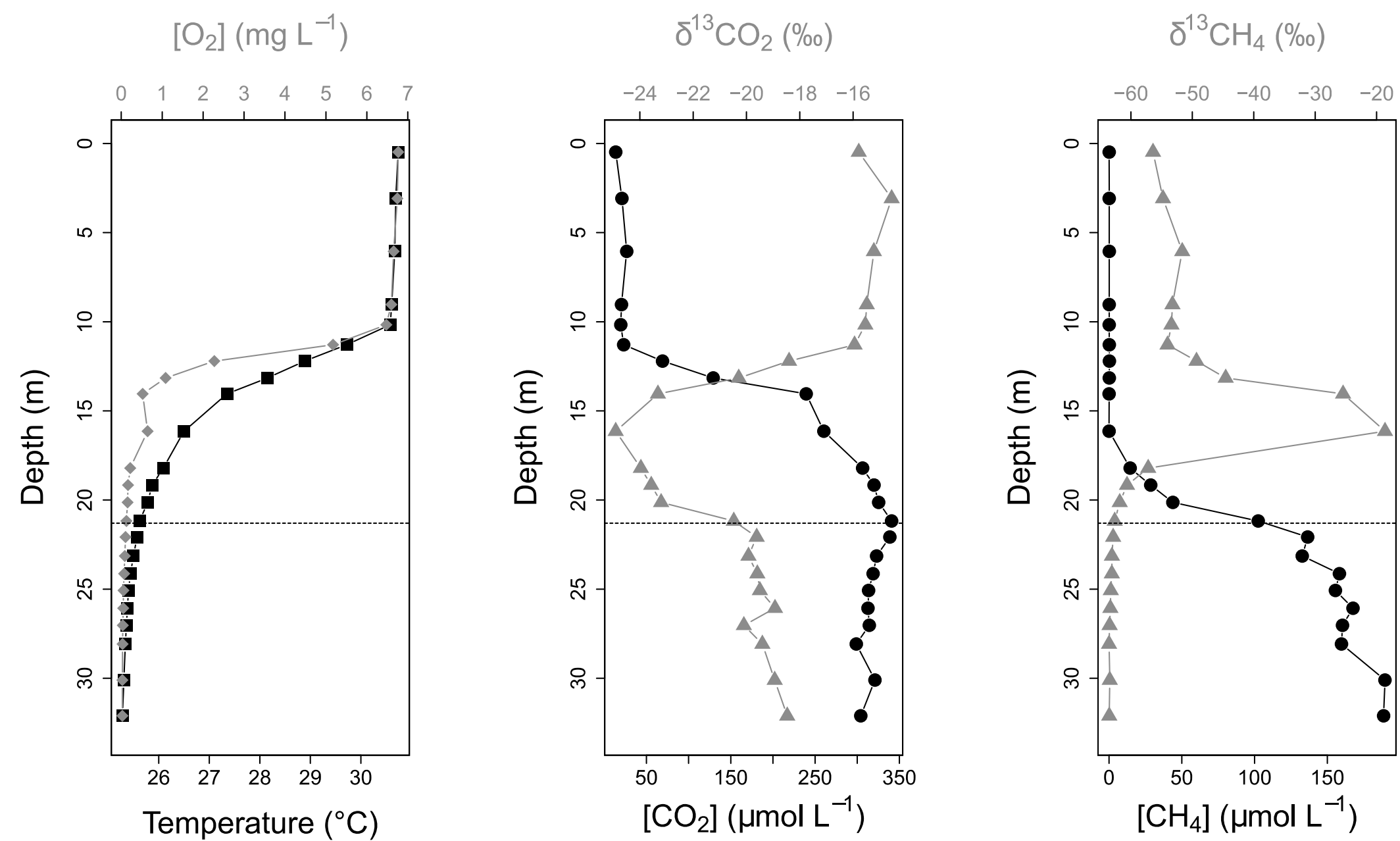

Figure S1: Profile example of water temperature (black squares), dissolved oxygen concentration (gray diamonds), $\mathrm{CO}_{2}$ and $\mathrm{CH}_{4}$ concentrations (black circles) and isotopic $\delta^{13} \mathrm{C}$ signature (gray triangles) in the main basin of the reservoir right upstream of the dam in Aug 2018. The horizontal dashed line represent the water withdrawal depth. 

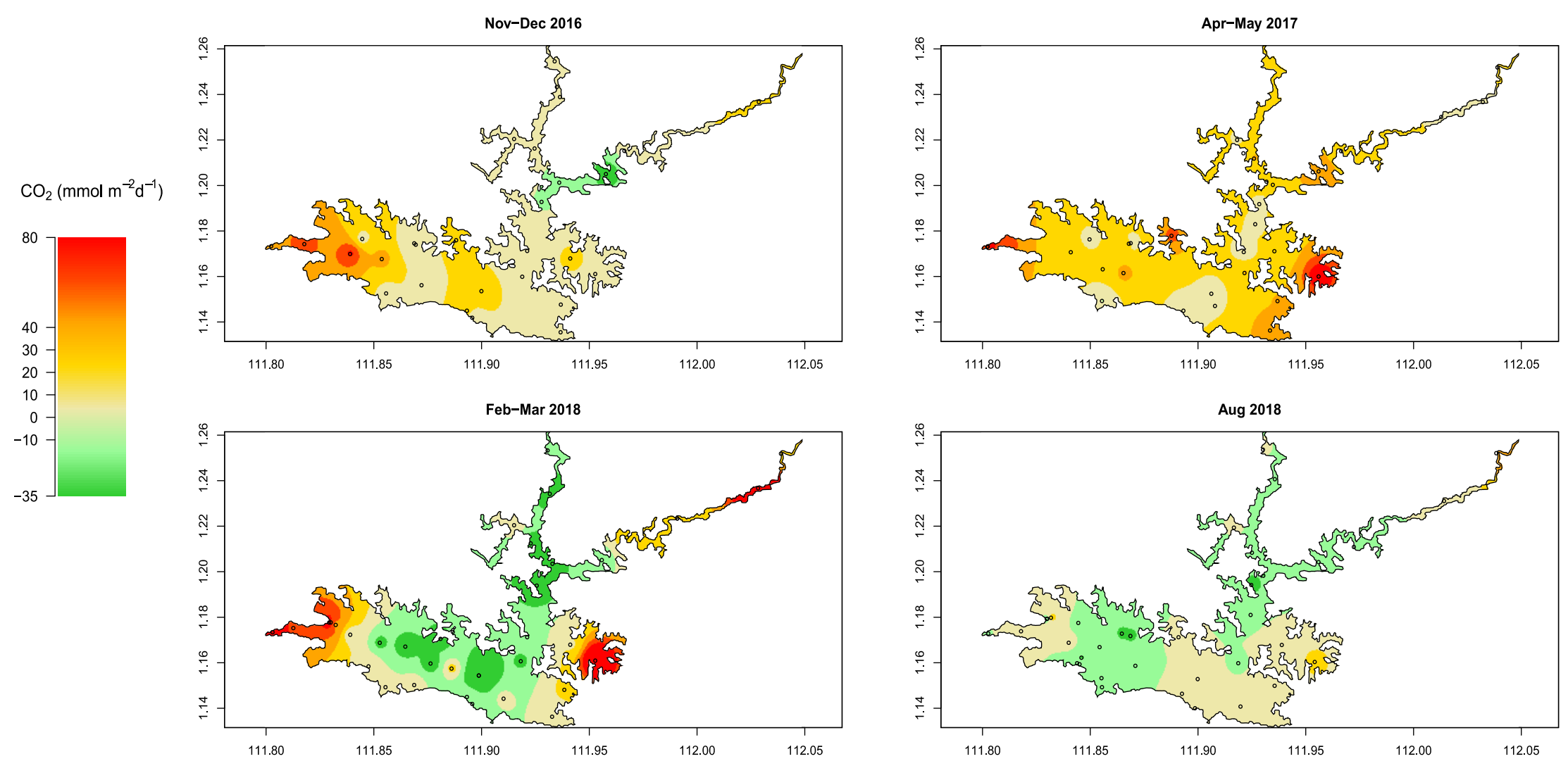

Figure S2: Maps of the spatially interpolated surface $\mathrm{CO}_{2}$ diffusion in Batang Ai reservoir for each sampling campaign. Unit is

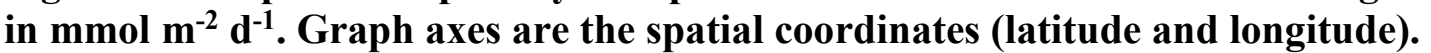



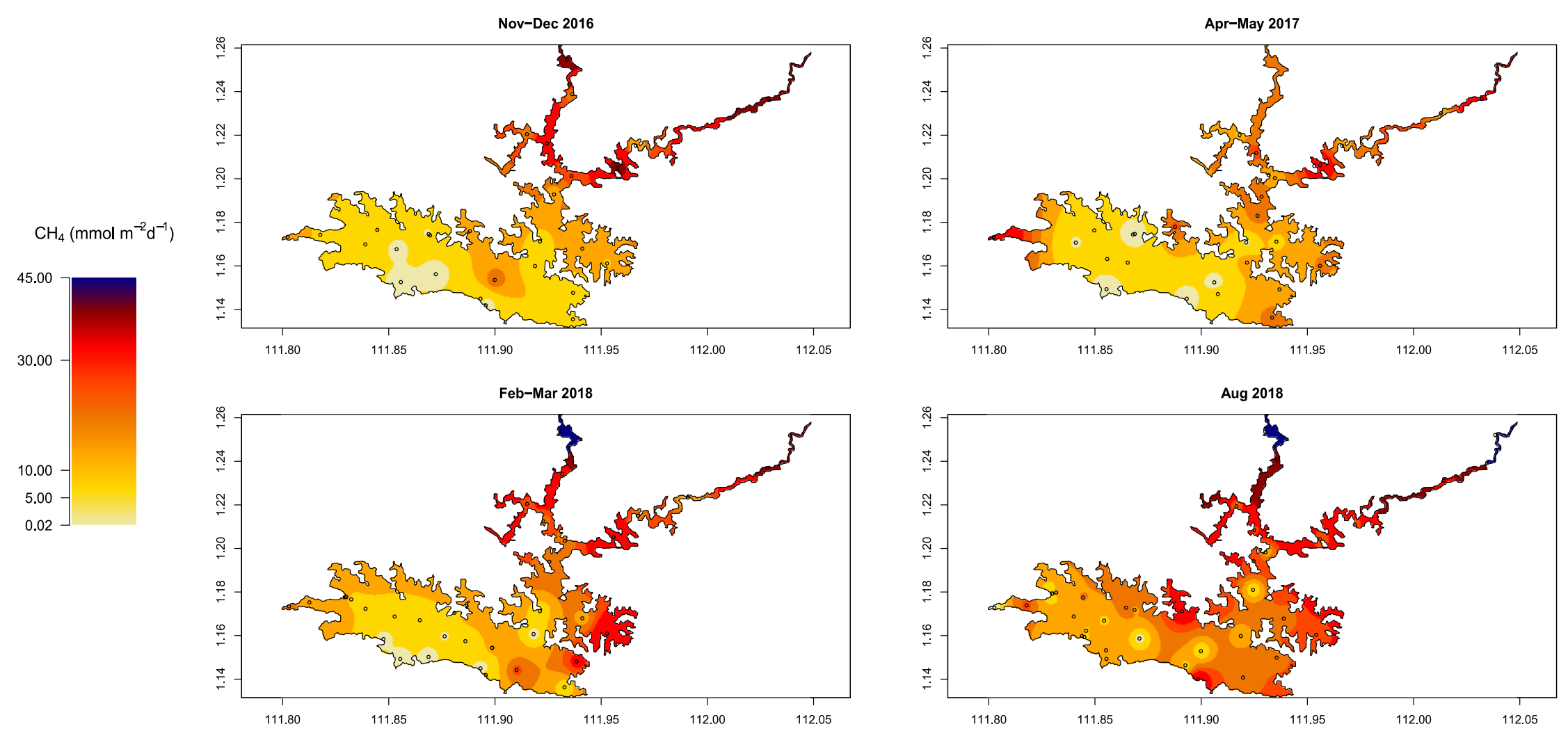

Figure S3: Maps of the spatially interpolated surface $\mathrm{CH}_{4}$ diffusion in Batang Ai reservoir for each sampling campaign. Unit is

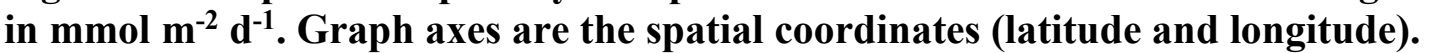




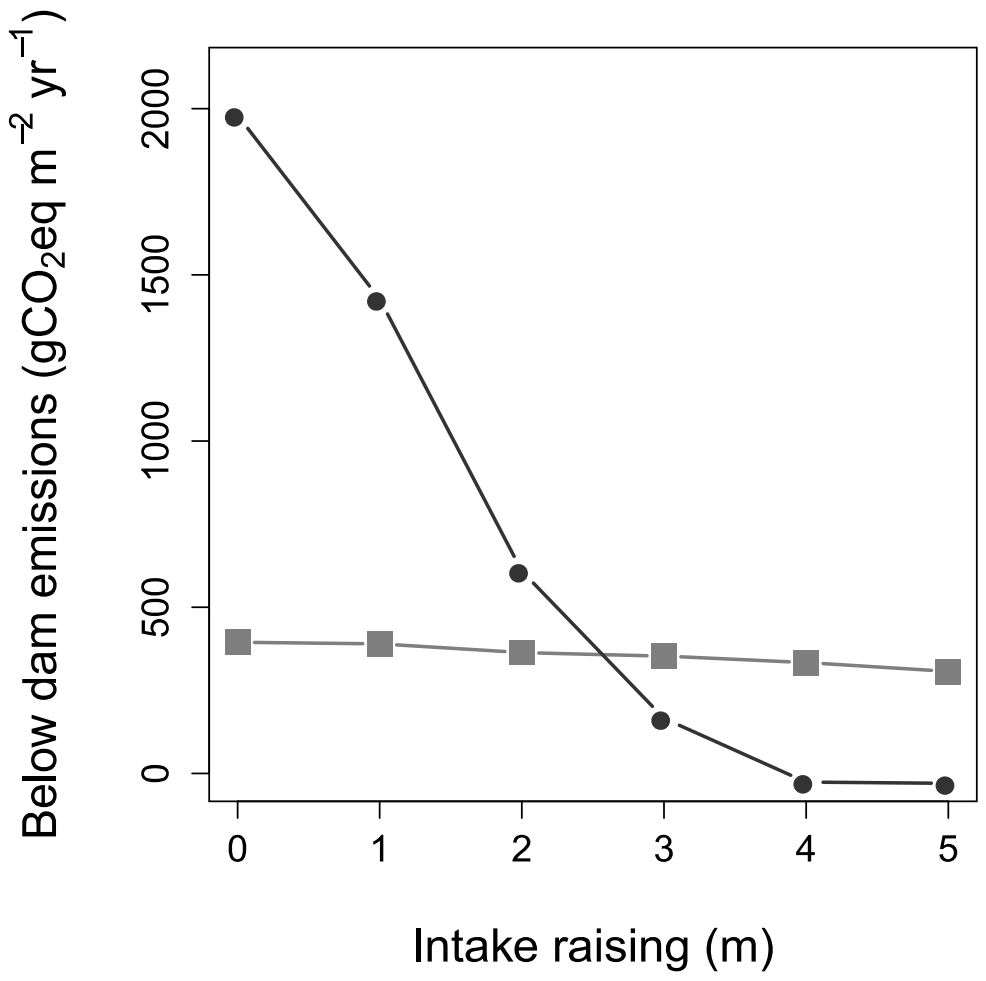

Figure S4: Simulated below dam emissions (degassing + downstream emissions) of $\mathrm{CO}_{2}$ (gray squares) and $\mathrm{CH}_{4}$ (black circles) under different water withdrawal depth raise. Simulated emissions do not take into account $\mathrm{CH}_{4}$ oxidation in the outflow river. 
Table S2: Equations used to derive modeled $\mathrm{CO}_{2}$ and $\mathrm{CH}_{4}$ emissions based on the G-res and Barros et al. models. Input variables are described in Table S3.

\begin{tabular}{|c|c|c|}
\hline & G-res model & Barros et al. model \\
\hline $\log _{10}\left(\mathrm{CO}_{2}\right.$ diffusion$)$ & $\begin{array}{c}1.7892-0.3364 \log _{10}(\mathrm{Age})+0.0400 \text { Effective temperature } \mathrm{CO}_{2}+ \\
0.06918 \log _{10} \text { (Reservoir area) }+0.0216 \text { Soil C content }+0.1472 \\
\log _{10}(\mathrm{TP})\end{array}$ & $\begin{array}{c}3.06-0.16 \log _{10}(\text { Age })-0.01 \text { Latitude }+0.41 \log _{10} \text { (DOC input) }- \\
\log _{10}(400)\end{array}$ \\
\hline $\log _{10}\left(\mathrm{CH}_{4}\right.$ diffusion) & $\begin{array}{c}0.8804-0.0116 \mathrm{Age}+0.6068 \log _{10}(\% \text { littoral area } / 100)+0.04828 \\
\text { Effective temperature } \mathrm{CH}_{4}\end{array}$ & $\begin{array}{c}1.33-0.36 \log _{10}(\text { Age })-0.32 \log _{10} \text { (Mean depth) }+0.39 \log _{10} \\
\text { (DOC input) - } 0.01 \text { Latitude }\end{array}$ \\
\hline $\log _{10}\left(\mathrm{CH}_{4}\right.$ ebullition $)$ & $\begin{array}{c}-0.98574+1.0075 \log _{10}(\% \text { littoral area } / 100)+0.04928 \\
\text { (Cumulative global horizontal radiance) }\end{array}$ & - \\
\hline $\mathrm{CH}_{4}$ degassing & $\begin{array}{c}10(-5.5029+2.2857 \log 10(\text { Modeled } \mathrm{CH} 4 \text { diffusion })+0.9866 \log 10(\text { Water residence time })) \\
\text { Discharge / Reservoir area }\end{array}$ & - \\
\hline
\end{tabular}


Table S3: Input variables values, units, and sources used in the modeling of Batang $\mathrm{Ai} \mathrm{CO}_{2}$ and $\mathrm{CH}_{4}$ emissions.

\begin{tabular}{|c|c|c|c|}
\hline Input variable & Value & Unit & Source \\
\hline \% Littoral area & 5.15 & $\%$ & $(1-(1-(3 /$ Maximum depth $))(($ Maximum depth / Mean depth $)-1)) \times 100$ \\
\hline Age & 33 & year & Mean reservoir age at sampling years (2016 - 2018) \\
\hline Annual runoff & 2219 & $\mathrm{~mm} \mathrm{yr^{-1 }}$ & UNH/GRDC Composite Runoff Fields V1.0 (Fekete et al., 2002) \\
\hline Catchment area & 1142 & $\mathrm{~km}^{2}$ & GranD database V1.3 (Lehner et al., 2011) \\
\hline Cumulative global horizontal radiance & 56.4 & $\mathrm{kWh} \mathrm{m} \mathrm{m}^{-2} \mathrm{yr}^{-1}$ & Surface meteorology and Solar Energy (NASA, 2008) \\
\hline Discharge & 106 & $\mathrm{~m}^{3} \mathrm{~s}^{-1}$ & Average during the four sampling times (provided by Sarawak Energy) \\
\hline $\mathrm{DOC}$ & 0.8 & $\mathrm{mg} \mathrm{L}^{-1}$ & Average of measured surface values in this study \\
\hline DOC input & 81.93 & $m g m^{-2} d^{-1}$ & (DOC $\times$ Volume) / (Reservoir area $\times$ Water residence time $\times 1000 \times 365)$ \\
\hline Effective temperature $\mathrm{CH}_{4}$ & 26.37 & ${ }^{\circ} \mathrm{C}$ & $\begin{array}{l}\text { Mean annual temperature corrected for the effect on } \mathrm{CH}_{4} \text { from G-res tool (Prairie } \\
\text { et al., 2017) }\end{array}$ \\
\hline Effective temperature $\mathrm{CO}_{2}$ & 26.37 & ${ }^{\circ} \mathrm{C}$ & $\begin{array}{l}\text { Mean annual temperature corrected for the effect on } \mathrm{CO}_{2} \text { from G-res tool (Prairie } \\
\text { et al., 2017) }\end{array}$ \\
\hline Latitude & 1.16 & Decimal degrees & Google earth \\
\hline Maximum depth & 85 & $\mathrm{~m}$ & GranD database V1.3 (Lehner et al., 2011) - Height dam wall \\
\hline Mean depth & 34.4 & $\mathrm{~m}$ & GranD database V1.3 (Lehner et al., 2011) \\
\hline Modeled $\mathrm{CH}_{4}$ diffusion & 134 & $\mathrm{gCO}_{2} \mathrm{eq} \mathrm{m}^{-2} \mathrm{yr}^{-1}$ & $\begin{array}{l}\text { Average over } 100 \text { years of } \mathrm{CH}_{4} \text { diffusion modeled based on the G-res equation } \\
\text { (Table S2) }\end{array}$ \\
\hline Reservoir area & 68.4 & $\mathrm{~km}^{2}$ & GranD database V1.3 (Lehner et al., 2011) \\
\hline Soil C content & 2.41 & $\mathrm{kgC} \mathrm{m} \mathrm{m}^{-2}$ & Estimated based on Wasli et al. 2011 \\
\hline $\mathrm{TP}$ & 6.77 & $\mu g L^{-1}$ & Average of measured surface values in this study \\
\hline Volume & $2360 \times 10^{6}$ & $\mathrm{~m}^{3}$ & GranD database V1.3 (Lehner et al., 2011) \\
\hline Water residence time & 0.93 & year & (Mean depth $\times$ Reservoir area) / (catchment area x Annual runoff) $\times 1000$ \\
\hline
\end{tabular}




\section{Modeling downstream river oxidation}

2 The following section describes the conceptual framework underlying the isotopic model used to

3 estimate $\mathrm{CH}_{4}$ oxidation in the outflow of the reservoir. For that, we assume that the only source of

4 water and $\mathrm{CH}_{4}$ to the outflow (starting right downstream of the power house) is the reservoir

5 discharge. We also assume oxidation and evasion to the atmosphere are the only two loss processes

6 for $\mathrm{CH}_{4}$ in the outflow, and that both reactions have a constant specific rate (they are a linear

7 function of $\mathrm{CH}_{4}$ concentration). When following a parcel of water travelling along the river, the

8 change in $\mathrm{CH}_{4}$ concentration can thus be described as:

$9 \quad \frac{d\left[\mathrm{CH}_{4}\right]}{d t}=-k_{\mathrm{oxi}}\left[\mathrm{CH}_{4}\right]-k_{\mathrm{eva}}\left[\mathrm{CH}_{4}\right]$,

10 with $k_{\text {oxi }}$ and $k_{\text {eva }}$ the rate coefficients of $\mathrm{CH}_{4}$ oxidation and evasion respectively, and [ $\mathrm{CH}_{4}$ ] the

$11 \mathrm{CH}_{4}$ concentration. Integration of Eq. (S1) yields the following generic time-depend solution:

$12\left[\mathrm{CH}_{4}\right]_{\mathrm{t}}=\left[\mathrm{CH}_{4}\right]_{0} e^{-\left(k_{\mathrm{oxi}}+k_{\mathrm{eva}}\right) \mathrm{t}}$,

13 The instantaneous oxidation rate at a given time $(\mathrm{t})$ or at a given point in the river is equal to:

14 oxidation rate $=k_{\mathrm{oxi}}\left[\mathrm{CH}_{4}\right]_{\mathrm{t}}$

15 Combining Eq. (S2) and Eq. (S3) yields the following equation:

16 oxidation rate $=k_{\text {oxi }}\left[\mathrm{CH}_{4}\right]_{0} e^{-\left(k_{\mathrm{oxi}}+k_{\mathrm{eva}}\right) \mathrm{t}}$,

17 Hence, the total amount of $\mathrm{CH}_{4}$ oxidized between time 0 and time $\mathrm{t}$ (or between $\mathrm{km} 0$ and $\mathrm{t}$ in the

18 river) is derived from the integration of Eq. (S4):

19 amount oxidized $=\int_{0}^{t} k_{\mathrm{oxi}}\left[\mathrm{CH}_{4}\right]_{0} e^{-\left(k_{\mathrm{oxi}}+k_{\mathrm{eva}}\right) t} d t$,

20 Simplifying Eq. (S5) yields:

21 amount oxidized $=\left[\mathrm{CH}_{4}\right]_{0}\left(\frac{k_{\mathrm{oxi}}}{\left(k_{\mathrm{oxi}}+k_{\mathrm{eva}}\right.}\right)\left(1-e^{-\left(k_{\mathrm{oxi}}+k_{\mathrm{eva}}\right) \mathrm{t}}\right)$, 
22 The amount oxidized can also be calculated as the product of the original $\mathrm{CH}_{4}$ concentration and

23 the fraction of $\mathrm{CH}_{4}$ oxidized $\left(\mathrm{F}_{\mathrm{ox}}\right)$ :

24 amount oxidized $=\left[\mathrm{CH}_{4}\right]_{0} \mathrm{~F}_{\mathrm{ox}}$,

25 According to Eq. (S6) and Eq. (S7), we can derive $F_{\text {ox }}$ from the following equation:

$26 \quad F_{\mathrm{ox}}=\left(\frac{k_{\mathrm{oxi}}}{\left(k_{\mathrm{oxi}}+k_{\mathrm{eva}}\right.}\right)\left(1-e^{-\left(k_{\mathrm{oxi}}+k_{\mathrm{eva}}\right) \mathrm{t}}\right)$,

27 In Eq. (S8), the second term of the product can be rearranged using Eq. (S2) to represent the 28 remaining fraction of $\mathrm{CH}_{4}$ concentration at time or $\mathrm{km} \mathrm{t}$ :

$29 \quad F_{\text {ox }}=\left(\frac{k_{\text {oxi }}}{\left(k_{\text {oxi }}+k_{\text {eva }}\right.}\right)\left(1-\frac{\left[C H_{4}\right]_{\mathrm{t}}}{\left[C H_{4}\right]_{0}}\right)$,

30 Given a fractionation factor $\alpha$ for $\mathrm{CH}_{4}$ oxidation, the behavior of the two $\mathrm{CH}_{4}$ isotopes $\left({ }^{12} \mathrm{CH}_{4}\right.$ and

$31{ }^{13} \mathrm{CH}_{4}$ ) can be described based on Eq. (S2) as following:

32

$$
\left[12 C H_{4}\right]_{\mathrm{t}}=\left[12 C H_{4}\right]_{0} e^{-\left(k_{\mathrm{oxi}}^{12}+k_{\mathrm{eva}}\right) \mathrm{t}}
$$

$33 \quad\left[13 \mathrm{CH}_{4}\right]_{\mathrm{t}}=\left[13 C H_{4}\right]_{0} e^{-\left(\frac{k_{\mathrm{Oxi}}^{12}}{\alpha}+k_{\mathrm{eva}}\right) \mathrm{t}}$,

34 With $\left[12 \mathrm{CH}_{4}\right]$ and $\left[13 \mathrm{CH}_{4}\right]$ the concentrations of the two isotopes, and $k_{\mathrm{oxi}}{ }^{12}$ the rate coefficient of 35 oxidation for the ${ }^{12} \mathrm{CH}_{4}$ isotope. The isotopic ratio of $\mathrm{CH}_{4}$ concentration at $\mathrm{t}\left(R_{\mathrm{t}}\right)$ can be derived 36 from Eq. (S10) and Eq. (S11) as following:

$37 \quad R_{\mathrm{t}}=\frac{\left[13 \mathrm{CH}_{4}\right]_{\mathrm{t}}}{\left[12 \mathrm{CH}_{4}\right]_{\mathrm{t}}}=\frac{\left[13 \mathrm{CH}_{4}\right]_{0} e^{-\left(\frac{k_{\text {oxi }}}{\alpha}+k_{\text {eva }}\right) \mathrm{t}}}{\left[12 \mathrm{CH}_{4}\right]_{0} e^{-\left(k_{\mathrm{oxi}}+k_{\text {eva }}\right) \mathrm{t}}}$

38 By simplifying Eq. (S12), $R_{\mathrm{t}}$ can be written as:

$39 \quad R_{\mathrm{t}}=R_{0} e^{\left(1-\frac{1}{\alpha}\right) \cdot k_{\mathrm{oxi}} \mathrm{t}}$,

40 The term $\mathrm{t}$ can be isolated from equation Eq. (S13): 
$41 \quad \mathrm{t}=\frac{\ln \left(R_{\mathrm{t}} / R_{0}\right)}{\left(1-\frac{1}{\alpha}\right) \cdot k_{\mathrm{oxi}}}$

42 Similarly, the term t can be isolated by rearranging Eq. (S2):

$43 \quad \mathrm{t}=\frac{\ln \left(\left[\mathrm{CH}_{4}\right]_{\mathrm{t}} /\left[\mathrm{CH}_{4}\right]_{0}\right)}{-\left(k_{\text {oxi }}+k_{\text {eva }}\right)}$,

44 Combining Eq. (S14) and Eq. (S15) results in:

$45 \quad \frac{\ln \left({ }^{R_{\mathrm{t}}} / R_{0}\right)}{\left(1-\frac{1}{\alpha}\right) \cdot k_{\text {oxi }}}=\frac{\ln \left(\left[\mathrm{CH}_{4}\right]_{\mathrm{t}} /\left[\mathrm{CH}_{4}\right]_{0}\right)}{-\left(k_{\text {oxi }}+k_{\text {eva }}\right)}$,

46 Rearranging E. (S16) yields:

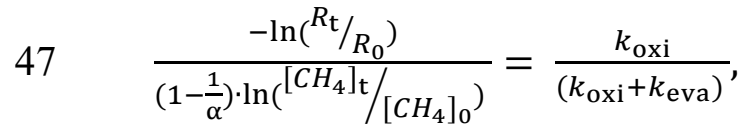

48 Using Eq. (S9) and Eq. (S17), we can derive $F_{\text {ox }}$ as:

$49 \quad F_{\text {ox }}=\frac{k_{\text {oxi }}}{\left(k_{\text {oxi }}+k_{\text {eva }}\right)}\left(1-\frac{\left[\mathrm{CH}_{4}\right]_{\mathrm{t}}}{\left[\mathrm{CH}_{4}\right]_{0}}\right)=\frac{-\ln \left({ }^{R \mathrm{t}} / R_{0}\right) \cdot\left(1-\left[\mathrm{CH}_{4}\right]_{\mathrm{t}} /\left[\mathrm{CH}_{4}\right]_{0}\right)}{\left(1-\frac{1}{\alpha}\right) \cdot \ln \left(\left[\mathrm{CH}_{4}\right]_{\mathrm{t}} /\left[\mathrm{CH}_{4}\right]_{0}\right)}$,

50 The isotopic ratios $\left(R_{\mathrm{t}}\right.$ and $\left.R_{0}\right)$ can be converted to $\delta^{13} \mathrm{CH}_{4}$ expressed in \%o using the following

51 standard isotopic equation calculation:

$52 \quad \delta^{13} \mathrm{CH}_{4}=\left(\frac{\left[13 \mathrm{CH}_{4}\right]:\left[12 \mathrm{CH}_{4}\right]}{\left[13 \mathrm{CH}_{4}\right]_{\text {std }}:\left[12 \mathrm{CH}_{4}\right]_{\text {std }}}-1\right) \times 1000$,

53 with $\left[13 \mathrm{CH}_{4}\right]_{\mathrm{std}}$ : $\left[12 \mathrm{CH}_{4}\right]_{\mathrm{std}}$ the standard reference Pee Dee Belemite isotopic carbon ratio. The 54 conversion of $R_{\mathrm{t}}$ and $R_{0}$ to $\delta^{13} \mathrm{CH}_{4}$ in Eq. (S18) results in the following equation for $F_{\text {ox }}$ calculation:

$55 \mathrm{~F}_{o x}=\frac{-\left[\ln \left(\delta^{13} \mathrm{CH}_{4 \mathrm{t}}+1000\right)-\ln \left(\delta^{13} \mathrm{CH}_{40}+1000\right)\right] \cdot\left(1-\left[\mathrm{CH}_{4}\right]_{\mathrm{t}} /\left[\mathrm{CH}_{4}\right]_{0}\right)}{\left(1-\frac{1}{\alpha}\right) \cdot \ln \left(\left[\mathrm{CH}_{4}\right]_{\mathrm{t}} /\left[\mathrm{CH}_{4}\right]_{0}\right)}$,

56 Eq. (S20) was used to determine $F_{\text {ox }}$ and $\mathrm{CH}_{4}$ oxidation (product of $\mathrm{F}_{\text {ox }}$ and $\left[\mathrm{CH}_{4}\right]_{0}$ ) in Batang Ai

57 river outflow using $\mathrm{km} 0$ and 19 as a start and end points of the river stretch. Sampling of $\mathrm{CH}_{4}$ 
58 concentration and isotopic signature was conducted at two other points within this river stretch 59 ( $\mathrm{km} 0.6$ and 2.7). This additional sampling resolution can help test the adequacy of the model and 60 its conceptual assumptions by recalculating $\mathrm{CH}_{4}$ oxidation in individual segments (between 0-0.6 $61 \mathrm{~km}, 0.6-2.7 \mathrm{~km}$, and 2.7-19 km). If the model assumptions are correct (absence of other $\mathrm{CH}_{4}$ source 62 in the river, constant specific oxidation rate, and constant river velocity), the amount of $\mathrm{CH}_{4}$ 63 oxidized in the entire stretch $\left(O x_{\text {total }}\right)$ should equal the sum of the amount oxidized in each 64 individual segment $\left(O x_{\text {sum }}\right)$. In two of the sampling campaigns (Apr-May 2017 and Feb-Mar 2018), 65 the difference between $O x_{\text {total }}$ and $O x_{\text {sum }}$ was very small $(\mathrm{CV}<5 \%)$. In the two other campaigns, 66 this difference was larger (CV of 12 and $35 \%$ for Nov-Dec 2016 and Aug 2018 respectively), due 67 to an additional $\mathrm{CH}_{4}$ source causing occasional increases of $\mathrm{CH}_{4}$ concentration along the stretch. 68 Overall, model assumptions appear reasonable, however, to avoid overestimating the amount 69 oxidized in cases of additional $\mathrm{CH}_{4}$ sources, we considered $O x_{\text {total }}$ as the more suitable estimate, 70 since it is less influenced by $\mathrm{CH}_{4}$ addition in individual segments. 
73 Fekete, B. M., Vörösmarty, C. J. and Grabs, W.: High-resolution fields of global runoff combining 74 observed river discharge and simulated water balances, Global Biogeochem. Cycles, 16(3), 15-175 15-10, doi:10.1029/1999GB001254, 2002.

76 Lehner, B., Liermann, C. R., Revenga, C., Vörösmarty, C., Fekete, B., Crouzet, P., Döll, P., 77 Endejan, M., Frenken, K., Magome, J., Nilsson, C., Robertson, J. C., Rödel, R., Sindorf, N. and 78 Wisser, D.: High-resolution mapping of the world's reservoirs and dams for sustainable river-flow 79 management, Front. Ecol. Environ., 9(9), 494-502, doi:10.1890/100125, 2011.

80 NASA: Surface meteorology and Solar Energy (SSE) Release 6.0 Data set, [online] Available 81 from: http://eosweb.larc.nasa.gov/sse/ (Accessed 18 June 2019), 2008.

82 Prairie, Y. T., Alm, J., Mercier-Blais, S. and Nahas, R.: The GHG Reservoir Tool ( G-res ) 83 Technical documentation, UNESCO/IHA research project on the GHG status of freshwater 84 reservoirs. Version 1.13., 2017.

85 Wasli, M. E., Tanaka, S., Kendawang, J. J., Abdu, A., Lat, J., Morooka, Y., Long, S. M. and 86 Sakurai, K.: Soils and Vegetation Condition of Natural Forests and Secondary Fallow Forests 87 within Batang Ai National Park Boundary, Sarawak, Malaysia, Kuroshio Sci., 5(1), 67-76, 2011. 